\title{
Research on the Application of Positive Psychology in Teaching of Ideological and Political Course among Higher Vocational Colleges
}

\author{
Lixia Bai \\ Shanxi Professional College of Finance
}

\begin{abstract}
Keywords: Positive Psychology; Higher Vocational Colleges; Ideological and Political Course

Abstract: As a branch of science, positive psychology has been proved beneficial for ideological and political course if it is properly utilized in the course among higher vocational colleges. Therefore, this paper focuses on the significance and effect of positive psychology in ideological and political course among higher vocational colleges.
\end{abstract}

\section{Introduction}

The modern society in the 21 st century has been developing in a diversified direction and its demand for talents has also become increasingly diversified. As an important part of China's education system, higher vocational colleges are mainly responsible for cultivating technical talents for the social development of our country, and play an important role in the overall development of society. Classroom teaching is an important part of higher vocational education and one of the principal channels for cultivating political accomplishment of college students. Effective classroom teaching activities of ideological and political education in higher vocational colleges play a critical role in guiding college students to establish an active outlook on world, life and values. However, there are various problems in the teaching of ideological and political course in higher vocational colleges affected by many factors which influence the comprehensive development of students. In order to promote the effectiveness classroom teaching activities, students should be taken into consideration and the contents of positive psychology be applied effectively to the teaching to improve their learning ability, develop their psychological quality, help students get a better standing in social development in the future and promote their overall progress and development.

2. Analysis of problems in the classroom teaching of ideological and political course among higher vocational colleges

Positive psychology, dating back to the last century, is a theory put forward by eminent American psychologists. Positive psychology, to put it simply, is a science devoted to studying the development potential of man and the positive qualities like virtue. Based on the Self-determination 
Theory, it empathizes that human is positive to make decisions on the basis of fully realizing the actual development of their own and external factors to promote overall progress and development. Therefore, this section is mainly the discussion and research of problems in the classroom teaching activities of ideological and political course among higher vocational colleges.

\subsection{The lack of innovative teaching in curriculum setting of ideological and political education among higher vocational colleges}

The effective classroom teaching activities in higher vocational colleges is self-evidently important both for the learning and social future development of students. However, one of the major problems existing in the teaching activities of ideological and political course in higher vocational colleges is that students are not interested in the studying this course, and the reasons for this problem are mainly in two aspects. On one hand, ideological and political courses setting in higher vocational colleges is not reasonable, and lacks individualized innovation in the course content, especially when the contents to be taught is disconnected from the development of the times, lacking effectiveness and novelty. On the other hand, in the process of carrying out teaching activities in the ideological and political course in higher vocational colleges, the teaching methods of are lack of innovation and are limited to the traditional teacher-dominant and students-supplemented mode, which fails to mobilize the enthusiasm of students to learn if it holds dominant position in the long term.

\subsection{Effective teaching cannot be conducted because of the languorous phenomenon of occupation in teachers.}

In the course of carrying out teaching activities of ideological and political course in higher vocational colleges, the existing problems are also reflected in the following aspects: First of all, teachers are listless when engage in ideological and political course in higher vocational colleges, which is also mainly reflected in two aspects. Firstly, due to the lack of passion and inspiration in classroom teaching, teachers just carry out classroom teaching activities as a task. Secondly, some teachers do not put enough attention to the effectiveness of ideological and political classroom teaching activities, resulting in unsatisfactory teaching effect. Then, in the course of teaching activities of ideological and political course in higher vocational colleges, the ideological and political course starts relatively later compared to other higher vocational courses, develops more slowly, and lacks targeted methods for effective teaching, so there is a variety of problems and imperfection in teaching activities of ideological and political course in higher vocational colleges.

\section{The effect of positive psychology in teaching activities of ideological and political course in higher vocational colleges}

The reason for applying positive psychology to ideological and political course is that it exerts positive influence on teaching activities of this course in higher vocational colleges in various aspects. Therefore, this section mainly discusses and clarifies the effect of positive psychology in teaching activities of ideological and political course in higher vocational colleges, laying the foundation for follow-up countermeasures.

\subsection{Guide students to learn the self-reflection and self-regulation, and cultivate their psychological quality}

Theoretically, positive psychology is the theory with positive psychology of human as the main content, emphasizes cultivating' positive and healthy psychology of students, and guides them to learn how to adjust themselves, which is in line with the core of ideological and political course teaching activities in higher vocational colleges. Therefore, applying positive psychology to 
ideological and political course teaching activities in higher vocational colleges is conducive to promoting students to learn self-regulation and self-reflection, so as to promote their own development. In addition, the continuous development of society requires more and more talents, especially well-rounded talents who are required not only excellent skills but also healthy mentality. Therefore, in ideological and political course teaching activities in higher vocational colleges, positive psychological theory can be applied to guide students to carry out psychological activities, develop optimistic attitude of students, promote the cultivation of their psychological quality, and further make progress in ideology and morality of students.

\subsection{Change the teaching languorous phenomenon in teachers, and achieve teaching objectives of ideological and political education.}

The application of positive psychology, for teaching activities of ideological and political course in higher vocational colleges helps change the traditional teaching mode, and guide teachers to better apply positive psychology in teaching activities and to be innovative in teaching methods, which is beneficial not only to transform languorous attitude of teachers, but also improve the quality of classroom teaching and the learning efficiency of students. On the other hand, applying positive psychology to the ideological and political course teaching in higher vocational colleges can realize the teaching objectives of ideological and political education, guide students to learn to think and solve problems in correct manner, and promote their overall progress and development.

\section{Discussion on the strategies of applying positive psychology to the teaching of ideological and political course in higher vocational colleges}

Positive psychology is applied to teaching activities of ideological and political course because problems exist in the current teaching activities of ideological and political course in higher vocational colleges in many aspects, and the application of positive psychology to teaching activities of ideological and political course can bring many benefits in many aspects, then, how to apply positive psychology effectively? This is the focus to be explored in this section. The proposal of the following strategies is hoped to provide some reference for the application of positive psychology to teaching activities of ideological and political course in higher vocational colleges so as to promote the development in all aspects.

\subsection{Respect the characteristics of ideological and political course, and combine the theory of positive psychology effectively.}

The teaching activities of ideological and political course in higher vocational colleges focus mainly on two levels, the first level is that effective teaching activities can reverse undesirable tendency in ideology of students to develop good ideological and moral qualities of students; the second level is to tap the potential of students themselves, stimulate them to learn independently and promote their overall development. At present, however, college students in our country generally have more or less problems in ideology and moral field, for example, it is not uncommon for suicides as a result of their poor psychological endurance, indicating the importance of strengthening teaching activities of ideological and political course. In applying positive psychology to teaching activities of ideological and political education in higher vocational colleges, it is to be noticed that in the reality, not only the teaching content and objectives of the ideological and political course should be combined, but also, in the view of positive psychology, positive psychology is to be applied to teaching activities of ideological and political course in higher vocational colleges in varying degree so as to enhance the quality of teaching activities. 


\subsection{Start with teachers, and innovate teaching form and content.}

In the application of positive psychology to teaching activities of ideological and political course in higher vocational colleges, first of all, teachers should take reasonable measures to promote the better application of positive psychology. To be more specific: Firstly, the core of positive psychology is the self-reported happiness, positive attitude and behavior. Therefore, as teachers of teaching activities of ideological and political course in higher vocational colleges, in order to apply positive psychology to teaching activities, teachers must start from themselves, improve self-personality, and be fully aware of the importance of this occupation and teaching activities carried out in specific aspects to enhance the sense of superiority of occupation, so as to be involved in the work with more positive mentality and enthusiasm. Secondly, under the guidance of positive psychology, teachers should create new forms and methods of ideological and political education in higher vocational education, focus on the reform of traditional teaching methods, adhere to the principle of taking the essence and discarding the dregs, and effectively carry out teaching activities combining the actual development of students. Specifically, in the course of carrying out the teaching activities of ideological and political course in higher vocational colleges, teachers create a positive classroom teaching atmosphere and adopt diversified interactive teaching modes to guide students to actively challenge themselves. At the same time, teachers' teaching should not be limited to classroom teaching activities, they, rather, should actively create conditions for students to combine the learning of theoretical knowledge and practical operation, and on this basis, deepen the understanding of what they have learned, which is not only beneficial to stimulate the interest in learning of students, but also plays an important role in cultivating ideological and moral qualities of them.

\subsection{Start with students, and take reasonable measures to improve the quality of teaching.}

In the course of applying positive psychology to teaching activities of ideological and political course in higher vocational colleges, secondly, measure should be taken from standpoints of students and teaching evaluation to promote the application of positive psychology. To be more specific: Firstly, the theory of positive psychology puts forward that human in social development have requirements in three aspects, sense of recognition, sense of belonging and ego needs separately. The growth of students is also closely related to the three aspects, which, whereas, is the key to conducting teaching activities of ideological and political course in higher vocational colleges successfully. Therefore, in the application of positive psychology to teaching activities of ideological and political course in higher vocational colleges, attention shall be paid to the growth need of students to mobilize their studying enthusiasm. Secondly, positive attitude and behavior are applied mainly in positive psychology to develop the potential of students. Therefore, the course of teaching activities of ideological and political course in higher vocational colleges shall to be student-oriented to guide the ideology and behaviour of students positively and lay a solid foundation for their development in an all-round way. Thirdly, researches in positive psychology have confirmed that those students with positive ideas have better social morals and better social adaptive capacity than peers, and that they can face stress, adversity and loss more easily even in the most unfavorable social environment. Therefore, there is a lot of practical significance to apply the theory of positive psychology to the course of ideological and political education in higher vocational colleges.

\section{Conclusions}

The application of positive psychology to the teaching of ideological and political course in higher vocational colleges is helpful not only to solve many problems existing in teaching but also 
play a significant role both in teaching and learning. Therefore, teachers should combine teaching practice and the basic theory of positive psychology to take effective measures, thus, promoting the application of positive psychology.

\section{References}

[1] Shallow Research on Effectiveness of Ideological and Political Theory Course in Higher Vocational Colleges-From the Perspective of Positive Psychology[J]. Xu Liuqing. Journal of Xiamen City Vocational College. $2015(03)$

[2] Exploration of Contradiction and Solutions in Teaching of Ideological and Political Theory Course[J]. Xie Yameng. Journal of Liaoning Teachers College(Social Sciences Edition). 2016(03)

[3] Conduct Participative Teaching to Make Teaching of Ideological and Political Theory Course "Alive" [J]. Zhang Ruirong. Extensive Collection of The Party History. 2015(07)

[4] Study and Exploration of the Cultivation of Socialist Core Values of Students in the Teaching of Ideological and Political Course in Higher Vocational Colleges[J]. Zhang Ruirong, Min Yingnan. Intelligence. 2015(22)

[5] New Exploration of Teaching of Ideological and Political Theory Course in Colleges from the Perspective of Positive Psychology[J]. Ma Liping. School Party Construction and Ideological Education. 2014(07)

[6] Further Discussion on the Selection of Teaching Case of Ideological and Political Theory Course in Higher Vocational Colleges[J]. Wu Haoran. Heihe Journal. 2014(04) 